\title{
SIMULTANEOUS DETERMINATION OF AMBROXOL, GUAIPHENESIN AND LEVOSALBUTAMOL SULPHATE IN PHARMACEUTICAL FORMULATIONS WITH THE USE OF FOUR RAPID DERIVATIVE SPECTROPHOTOMETRIC METHODS
}

\author{
GAGANDEEP, NAVDEEP KAUR GILL, KARAN, G S SARMA, ARTI THAKKAR* \\ Department of Pharmaceutical Analysis, ISF College of Pharmacy, Ferozepur Road, Ghal Kalan, Moga - 142 001, Punjab, India.
}

(Received: May 7, 2012 - Accepted: August 19, 2012)

\begin{abstract}
Four simple, rapid, accurate, precise, reliable and economical spectrophotometric methods have been proposed for simultaneous determination of ambroxol, guaiphenesin and levosalbutamol sulphate, in pure and pharmaceutical formulations without any prior separation or purification step. The methods are first derivative zero crossing spectrophotometry, simultaneous equation, derivative ratio spectra zero crossing and double divisor ratio spectra derivative method. Developed methods show best results in terms of linearity, accuracy, precision, LOD and LOQ for standard laboratory mixtures of pure drugs and marketed formulations. Common excipients and additives did not interfere in determinations of these APIs. Results obtained by the proposed methods have been statistically compared by means of student $t$-test.
\end{abstract}

Keywords: Simultaneous equation method; Derivative ratio spectra zero crossing spectrophotometry; Double divisor ratio spectra derivative spectrophotometry; Ambroxol; Guaiphenesin, Levosalbutamol sulphate.

\section{INTRODUCTION}

Ambroxol $\mathrm{HCl}(\mathrm{AB})$ chemically known as trans-4-(2-Amino-3,5dibrombenzylamino)-cyclohexanol hydrochloride, is a secretolytic agent used in the treatment of respiratory diseases associated with viscid or excessive mucus. Levosalbutamol sulphate (LS) chemically known as 4-[(1R)-2-(tertbutylamino)-1-hydroxyethyl]- 2-(hydroxymethyl) phenol, it is used to treat asthma and chronic obstructive pulmonary disease. Guaiphenesin (GF) chemically known as (RS)-3-(2-methoxyphenoxy) propane-1,2-diol, an expectorant that also has some muscle relaxing action. AB [1] and GF [2] [3] are official in IP and BP. The official methods involve determination of AB [4] and GF [5] using potentiometer for pure drug but method has not been described for formulation.

Some procedures have been described for the assay of either LS or $\mathrm{AB}$ or GF in single dosage forms [4-7]. AB, GF and LS mixture is not yet official in any pharmacopoeia but few formulations are available in generic market. As per literature, no analytical methods could be traced for the analysis of $\mathrm{AB}, \mathrm{GF}$ and LS combination in pharmaceutical dosage forms. Therefore simple, rapid and reliable methods for simultaneous estimation of these drugs in mixture seemed to be necessary.

Spectrophotometric methods of analysis are more economic and simpler, compared to methods such as chromatography and electrophoresis. Under computer-controlled instrumentation, derivative spectrophotemetry is playing a very important role in the multicomponent analysis of mixtures by ultravioletvisible molecular absorption spectrophotometry [7]. Ternary mixtures can be easily resolved by means of a spectrophotometric method, which is based on the simultaneous use of "zero-crossing" and "ratio spectra derivative" methods [7-8]. The aim of this work is to investigate the utility of derivative spectrophotometry and to develop reliable spectrophotometric procedures for the simultaneous determination of $\mathrm{AB}, \mathrm{GF}$ and LS either in laboratory samples, or in commercial dosage forms without any prior separation of individual drugs. $\mathrm{AB}, \mathrm{GF}$ and LS have closely overlapping spectra, which prevents the use of zero-order UV-VIS spectrophotometry for their determination. Derivative spectrophotometry is a very useful tool for overcoming this problem. This technique has been successfully applied in pharmaceutical and environmental analysis for determination of drugs in multicomponent systems [8-9].

In this work, various orders of derivative and different kinds of measurements were assayed, i.e., zero-crossing first derivative [8-10], simultaneous equation method [11-12], ratio-spectra first derivative zero crossing [13] and double divisor ratio spectra derivative method [14]. Four methods have been successfully developed for mentioned combination and satisfactory results were obtained. A brief comparison between usefulness of different procedures was attempted.

\section{EXPERIMENTAL}

\section{Instruments}

Spectrophotometric measurements were made on a Shimadzu 1700 double beam UV Visible spectrophotometer with a fix slit width of $1 \mathrm{~nm}$ coupled with computer loaded with Shimadzu UV Probe software of version 2.31.

Reagents

All chemicals used were of analytical grade and double distilled water was used throughout. Pure AB was obtained from Divine Pharmaceuticals Pvt. Ltd., India and LS and GF were obtained from COSMOS Research Lab, India. Various pharmaceutical formulations of AB, GF and LS in their combined dosage forms were obtained from local market (Ascoril LS, Batch No: 52120012, Mfg Date: Jan 2012, Expiry Date: Dec. 2013, Glenmark Pharmaceuitcal Ltd).

Solutions

Stock solutions, $1 \mathrm{mg} \mathrm{mL}^{-1}$ in distilled water, of pure samples of LS, AB and GF were freshly prepared individually. Syrup dosage form Ascoril LS containing $0.5 \mathrm{mg}$ of LS, $15 \mathrm{mg}$ of $\mathrm{AB}$ and $50 \mathrm{mg}$ of GF. Each time $5 \mathrm{ml}$ of liquid formulation was used for the study.

Procedure

All reagents were tested for stability in solution and during the actual analysis. The behavior of the analytes remained unchanged up to about 24 $\mathrm{h}$ from their preparation at the room temperature. All the three drugs were found to be stable during each kind of experimental measurements. Each measurement was done at room temperature.

Third derivative zero crossing spectrophotometry (Method 1)

Absorption spectra of the samples were recorded between 220- $400 \mathrm{~nm}$ against a reagent blank (same samples without compounds to be determined) using a $1.0 \mathrm{~cm}$ quartz cell. Zero order spectra of pure drugs were stored individually within above concentration ranges and were derivatized in third order using delta lambda 4 and scaling factor 10 for all three drugs. The third derivative amplitudes were recorded at $252.2 \mathrm{~nm}, 282.6 \mathrm{~nm}$ and $285 \mathrm{~nm}$ for determination of $\mathrm{AB}, \mathrm{GF}$ and $\mathrm{LS}$ respectively. Standard laboratory mixtures of $\mathrm{AB}, \mathrm{GF}$ and LS in 15: 50: 0.5 ratios were prepared and absorbance was measured at $252.2 \mathrm{~nm}, 282.6 \mathrm{~nm}$ and $285 \mathrm{~nm}$ for AB, GF and LS respectively.

Simultaneous equation method (Method 2)

This method is based on third derivative and wavelengths selected for estimation of $\mathrm{AB}, \mathrm{GF}$ and $\mathrm{LS}$ were $252.2 \mathrm{~nm}, 282.6 \mathrm{~nm}$ and $285 \mathrm{~nm}$ respectively. However, in contrast to first method, this method utilized simultaneous equations (Vierdot's method) on derivative spectra to overcome spectral interference at selected wavelength. The first derivative absorptivity coefficients were determined at the selected wavelengths. A set of three equations framed using these coefficient values were listed below:

$$
\begin{aligned}
& \mathrm{C}_{\mathrm{AB}}=\mathrm{DA}_{\mathrm{AB}} 1980.009(1) \\
& \mathrm{C}_{\mathrm{GF}}=\mathrm{DA}_{\mathrm{GF}} 395.8294(2) \\
& \mathrm{C}_{\mathrm{LS}}=\mathrm{DA}_{\mathrm{LS}} 1902.973(3)
\end{aligned}
$$


Where, $\mathrm{C}_{\mathrm{AB}}, \mathrm{C}_{\mathrm{GF}}$ and $\mathrm{C}_{\mathrm{LS}}$ are the concentration of $\mathrm{AB}$, GF and LS respectively; $\mathrm{DA}_{\mathrm{AB}}, \mathrm{DA}_{\mathrm{GF}}$ and $\mathrm{DA}_{\mathrm{LS}}$ are the first derivative amplitudes of mixture at $252.2 \mathrm{~nm}, 282.6 \mathrm{~nm}$ and $285 \mathrm{~nm}$. These equations were directly utilized for simultaneous estimation of $\mathrm{AB}, \mathrm{GF}$ and LS in standard laboratory mixture as well as the marketed formulations.

Derivative ratio spectra zero crossing spectrophotometry (Method 3)

Absorption spectra of pure drugs and their ternary mixtures were recorded between $210-320 \mathrm{~nm}$. Absorption spectra of pure $\mathrm{AB}$ and their ternary mixture were divided by a standard spectrum of $20 \mu \mathrm{g} \mathrm{mL}^{-1}$ of LS, absorption spectra of pure GF and their ternary mixture were divided by a standard spectrum of $20 \mu \mathrm{g} \mathrm{mL}^{-1}$ of LS and absorption spectra of pure LS and their ternary mixture were divided by a standard spectrum of $20 \mu \mathrm{g} \mathrm{mL}^{-1}$ of GF and first derivative of the ratio spectra were plotted using delta lambda $8 \mathrm{~nm}$ and scaling factor 10 . In the ternary mixture, concentration of $\mathrm{AB}, \mathrm{GF}$ and $\mathrm{LS}$ were proportional to the first derivative ratio signals at $297 \mathrm{~nm}$ (zero crossing point for GF where $20 \mu \mathrm{g}$ $\mathrm{mL}^{-1}$ of LS was used as divisor), $275.6 \mathrm{~nm}$ (zero crossing point for AB where 20 $\mu \mathrm{g} \mathrm{mL}^{-1}$ of LS was used as divisor) and $227.5 \mathrm{~nm}$ (zero crossing point for $\mathrm{AB}$ where $20 \mu \mathrm{g} \mathrm{mL}^{-1}$ of GF was used as divisor) respectively. Calibration graphs were obtained by measuring the derivative ratio amplitudes against increasing concentration of pure $\mathrm{AB}$, pure $\mathrm{GF}$ and pure LS using respective divisors. Contents of $\mathrm{AB}, \mathrm{GF}$ and LS in standard laboratory mixture and commercial formulation were determined by use of above mentioned procedure.

Double divisor ratio spectra derivative method (Method 4)

Absorption spectra of the pure drugs and their ternary mixtures were recorded between $210-320 \mathrm{~nm}$. The absorption spectra of AB and their ternary mixture were divided by a standard spectrum obtained by the addition of stored spectrum of $20 \mu \mathrm{g} \mathrm{mL}^{-1}$ of LS and $20 \mu \mathrm{g} \mathrm{mL}^{-1}$ of GF and first derivative of the ratio spectra was plotted using delta lambda $4 \mathrm{~nm}$ and scaling factor 1 . In the ternary mixture, concentration of $\mathrm{AB}$ was proportional to first derivative ratio signals at $240.4 \mathrm{~nm}$. Calibration graph was obtained by measuring derivative ratio amplitudes against increasing concentration of pure $\mathrm{AB}$ by using same divisor described above. Content of $\mathrm{AB}$ was determined by use of above mentioned calibration graph. Similarly, for determination of GF, a standard spectrum obtained by the addition of stored spectrum of $20 \mu \mathrm{g} \mathrm{mL}^{-1}$ of $\mathrm{LS}$ and $20 \mu \mathrm{g} \mathrm{mL} \mathrm{m}^{-1}$ of $\mathrm{AB}$ was used as divisor and for LS determination, a standard spectrum obtained by the addition of stored spectrum of $20 \mu \mathrm{g}$ $\mathrm{mL}^{-1}$ of $\mathrm{GF}$ and $20 \mu \mathrm{g} \mathrm{mL}^{-1}$ of $\mathrm{AB}$ used as divisor. First derivative of the ratio spectra were plotted using delta lambda were $4 \mathrm{~nm}$ and scaling factor 1 . In the ternary mixture, the concentration of GF and LS were proportional to the first derivative ratio signals at $262.4 \mathrm{~nm}$ and $289.1 \mathrm{~nm}$ respectively. Calibration graphs were obtained by measuring the derivative ratio amplitudes against increasing concentration of pure GF and LS by using same respective divisors described above.

\section{RESULTS AND DISCUSSION}

Absorption spectra of the three compounds LS, AB and GF overlapped closely shown in Fig. 1. It is clearly observed that determination of these compounds was not possible by direct measurements of absorbance in zeroorder spectra. On the other hand, derivative spectroscopy shows more resolution and makes it possible to analyze each drug in presence of one another as well as in the presence of other excipients without requirement of any pretreatment.

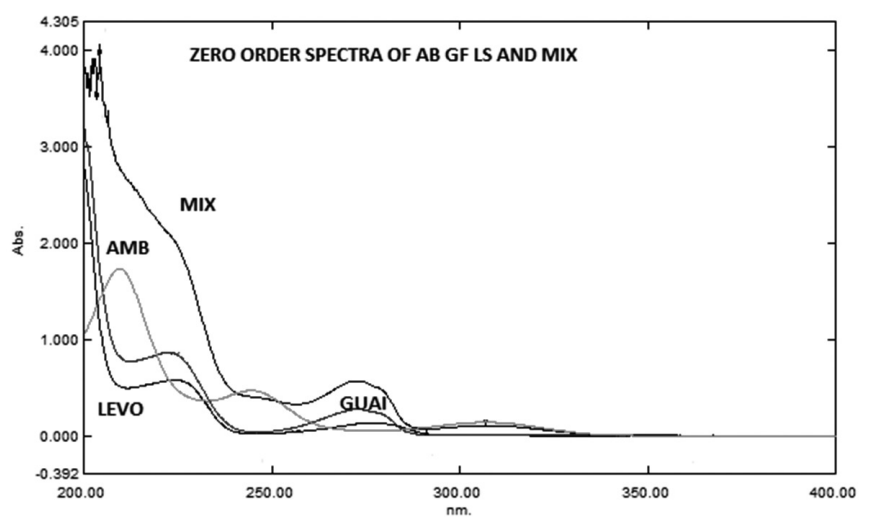

Figure1: Zero order overlain spectra of $\mathrm{AB}\left(20 \mu \mathrm{g} \mathrm{mL}^{-1}\right), \mathrm{GF}(20 \mu \mathrm{g} \mathrm{mL}$ $\left.{ }^{1}\right), \mathrm{LS}(20 \mu \mathrm{g} \mathrm{mL}-1)$ and their ternary mixture.
Third derivative zero crossing spectrophotometry (Method 1)

In contrast to zero order spectra, third derivative spectra show more resolution in terms of zero-crossing points shown in Fig. 2. The third derivative wavelengths were considering $252.2 \mathrm{~nm}$ for $\mathrm{AB}, 282.6 \mathrm{~nm}$ for $\mathrm{GF}$ and 285 $\mathrm{nm}$ for LS determination. At $252.2 \mathrm{~nm}$ there is not contribution of GF and $\mathrm{LS}, \mathrm{AB}$ was determined at this wavelength in the presence of other two drugs represented in Fig 3a. At $282.6 \mathrm{~nm}$, both AB and LS show zero absorbance; therefore GF was determined at this wavelength without any interference of other two represented in Fig. 3b. At $285 \mathrm{~nm}$ LS was determined because it was zero crossing point for both $\mathrm{AB}$ and GF shown in Fig. 3c. The developed method was validated accurately and results of accuracy are shown in Table 1 , summary of various validation parameters are listed in Table 2 and 3 , results of marketed formulation analysis are listed in Table 4.

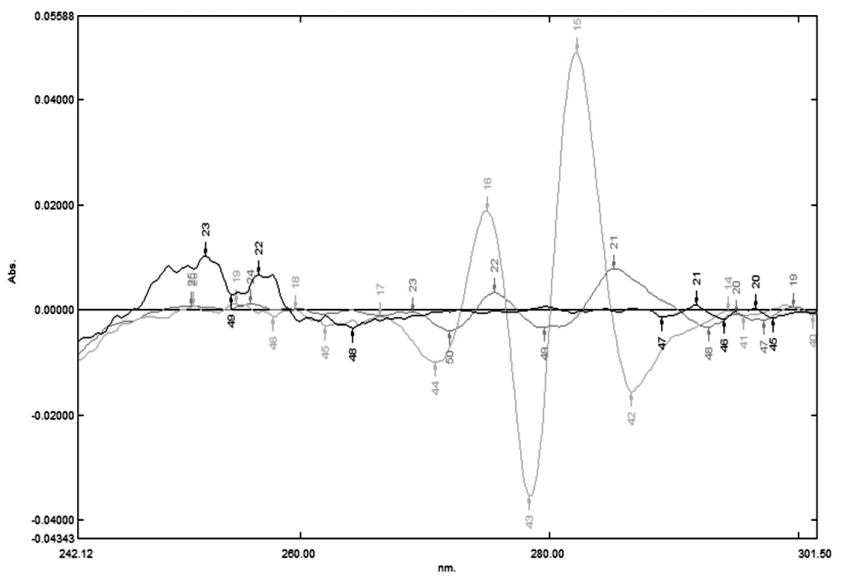

Figure2: Third derivative overlain spectra of $\mathrm{AB}, \mathrm{GF}$ and LS.

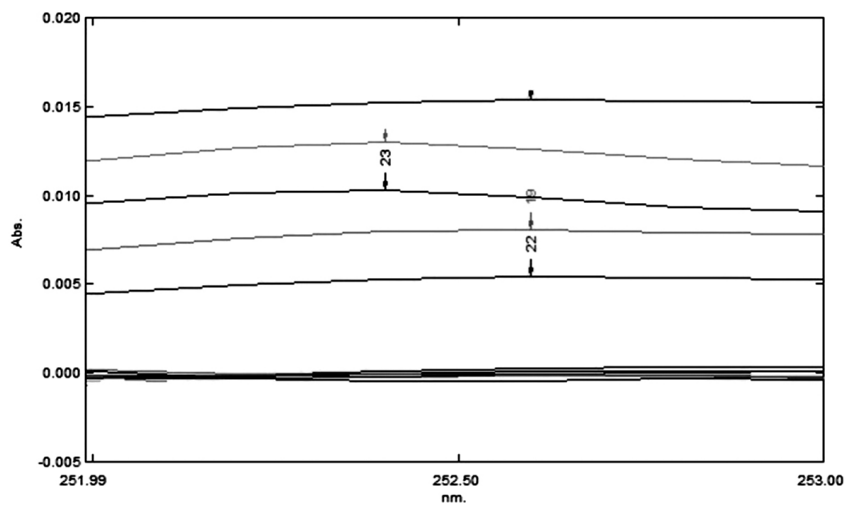

Figure3a: Determination of $\mathrm{AB}$ at $252.2 \mathrm{~nm}$ by Method 1 in the presence of GF and LS.

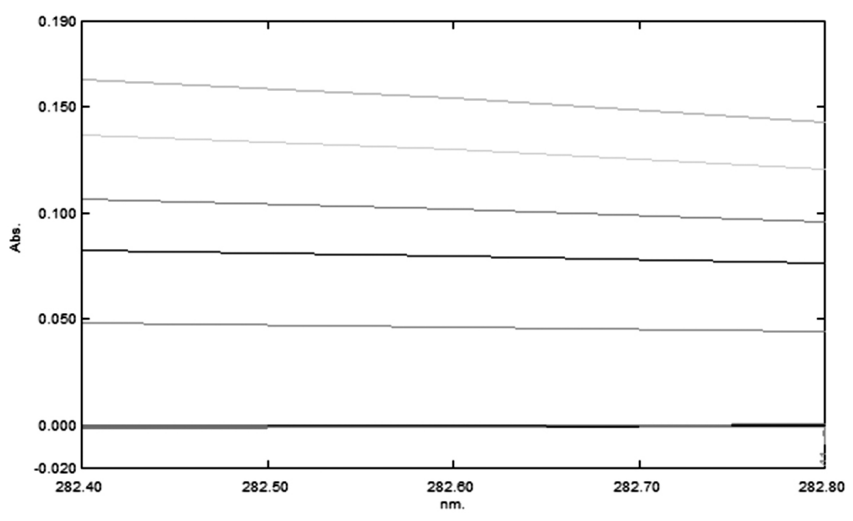

Figure3b: Determination of GF at $282.6 \mathrm{~nm}$ by Method 1 in the presence of $\mathrm{AB}$ and $\mathrm{LS}$. 


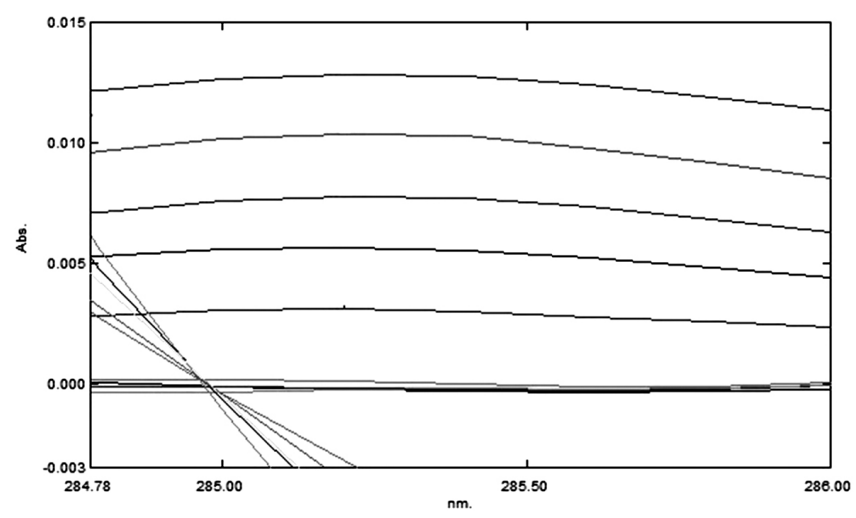

Figure3c: Determination of LS at $285 \mathrm{~nm}$ by Method 1 in the presence of AB and GF.

Table 1: Results of recovery study of AB, GF and LS by all four methods.

\begin{tabular}{|c|c|c|c|c|c|c|c|c|c|c|c|c|c|c|}
\hline \multicolumn{3}{|c|}{$\begin{array}{l}\text { Amt added } \\
\left(\mu \mathrm{g} \mathrm{mL} L^{-1}\right)\end{array}$} & \multicolumn{3}{|c|}{$\begin{array}{c}\% \text { Recovery } \\
\text { Method } 1\end{array}$} & \multicolumn{3}{|c|}{$\begin{array}{l}\% \text { Recovery }{ }^{\mathrm{a}} \\
\text { Method } 2\end{array}$} & \multicolumn{3}{|c|}{$\begin{array}{l}\text { \% Recovery } \\
\text { Method } 3\end{array}$} & \multicolumn{3}{|c|}{$\begin{array}{l}\% \text { Recovery }^{\mathrm{a}} \\
\text { Method } 4\end{array}$} \\
\hline $\mathrm{AB}$ & GF & LS & $\mathrm{AB}$ & GF & LS & $\mathrm{AB}$ & GF & LS & $\mathrm{AB}$ & GF & LS & $\mathrm{AB}$ & GF & LS \\
\hline 12 & 40 & 0.4 & 99.44 & 99.06 & 98.22 & 99.41 & 99.50 & 99.76 & 99.65 & 99.37 & 99.79 & 99.29 & 99.74 & 99.51 \\
\hline 15 & 50 & 0.5 & 99.56 & 101.96 & 98.27 & 99.00 & 99.51 & 99.59 & 100.88 & 99.90 & 99.84 & 99.48 & 99.92 & 99.36 \\
\hline 18 & 60 & 0.6 & 99.26 & 99.37 & 97.89 & 99.66 & 99.32 & 99.12 & 99.40 & 99.17 & 99.21 & 99.11 & 99.84 & 99.77 \\
\hline \multicolumn{3}{|c|}{ Mean Recovery } & 99.42 & 100.13 & 98.12 & 99.35 & 99.443 & 99.49 & 99.98 & 99.48 & 99.61 & 99.29 & 99.83 & 99.83 \\
\hline \multicolumn{3}{|c|}{ SD } & 0.1497 & 1.593 & 0.2052 & 0.333 & 0.106 & 0.33 & 0.793 & 0.37 & 0.347 & 0.18 & 0.09 & 0.21 \\
\hline
\end{tabular}

a - Mean and standard deviation for 10 determinations

Table 2: Results of validation parameters obtained by method 1 and method 2 .

\begin{tabular}{|c|c|c|c|c|c|c|}
\hline \multirow{2}{*}{ Parameters } & \multicolumn{3}{|c|}{ Method 1} & \multicolumn{3}{|c|}{ Method 2} \\
\hline & $\mathrm{AB}$ & GF & LS & $\mathrm{AB}$ & GF & LS \\
\hline Linearity & 0.9945 & 0.9957 & 0.9965 & 0.9945 & 0.9957 & 0.9965 \\
\hline $\operatorname{Range}\left(\mu \mathrm{g} \mathrm{mL}^{-1}\right)$ & $10-30$ & $20-60$ & $5-25$ & $10-30$ & $20-60$ & $5-25$ \\
\hline Accuracy & $99.42 \pm 0.1497$ & $100.13 \pm 1.5939$ & $98.13 \pm 0.2052$ & $99.35 \pm 0.333$ & $99.44 \pm 0.106$ & $99.49 \pm 0.33$ \\
\hline $\begin{array}{l}\text { Precision } \\
\text { (\% RSD) }\end{array}$ & 1.253 & 1.092 & 1.02 & 1.253 & 1.092 & 1.02 \\
\hline $\operatorname{LOD}\left(\mu \mathrm{g} \mathrm{mL}^{-1}\right)$ & 0.983 & 0.3058 & 0.798 & 0.983 & 0.3058 & 0.798 \\
\hline $\mathrm{LOQ}\left(\mu \mathrm{g} \mathrm{mL}^{-1}\right)$ & 2.98 & 0.9266 & 2.42 & 2.98 & 0.9266 & 2.98 \\
\hline $\begin{array}{l}\text { Reproducibility } \\
\text { (\% RSD) }\end{array}$ & 0.9203 & 0.9179 & 0.8451 & 0.9203 & 0.9179 & 0.8451 \\
\hline
\end{tabular}

Table 3: Results of validation parameters of method 3 and method 4.

\begin{tabular}{|c|c|c|c|c|c|c|}
\hline \multirow{2}{*}{ Parameters } & \multicolumn{3}{|c|}{ Method 3} & \multicolumn{3}{|c|}{ Method 4} \\
\hline & $\mathrm{AB}$ & GF & LS & $\mathrm{AB}$ & GF & LS \\
\hline Linearity & 0.9956 & 0.9933 & 0.9911 & 0.9979 & 0.9976 & 0.9963 \\
\hline $\operatorname{Range}\left(\mu \mathrm{g} \mathrm{mL}^{-1}\right)$ & $10-30$ & $20-60$ & $5-25$ & $10-30$ & $20-60$ & $5-25$ \\
\hline Accuracy & $99.98 \pm 0.80$ & $99.48 \pm 0.38$ & $99.61 \pm 0.34$ & $99.29 \pm 0.18$ & $99.83 \pm 0.09$ & $99.55 \pm 0.21$ \\
\hline $\begin{array}{l}\text { Precision } \\
(\% \text { RSD })\end{array}$ & 0.7555 & 0.5885 & 0.4342 & 0.2496 & 0.9814 & 0.3810 \\
\hline $\mathrm{LOD}\left(\mu \mathrm{g} \mathrm{mL}^{-1}\right)$ & 0.06 & 0.011 & 0.8 & 0.002 & 0.006 & 0.034 \\
\hline $\mathrm{LOQ}\left(\mu \mathrm{g} \mathrm{mL}^{-1}\right)$ & 0.19 & 0.033 & 2.59 & 0.009 & 0.01 & 0.104 \\
\hline $\begin{array}{l}\text { Reproducibility } \\
\text { (\% RSD) }\end{array}$ & 0.9687 & 0.5110 & 0.3473 & 0.5459 & 0.8480 & 0.5971 \\
\hline
\end{tabular}


Table 4: Assay results of AB, GF and LS in combined commercial formulations by Method 1.

\begin{tabular}{|c|c|c|c|}
\hline \multirow{2}{*}{ Formulation } & \% Labeled Claim obtained & \% Labeled Claim obtained & \% Labeled Claim obtained \\
& $\mathrm{AB}$ & $\mathrm{GF}$ & LS \\
\hline \multirow{2}{*}{ Ascoril LS } & $98.67 \pm 0.001$ & $97.01 \pm 0.0002$ & $98.94 \pm 0.0001$ \\
\hline
\end{tabular}

d - Mean and standard deviation for 10 determinations.

Table 5: Assay results of AB, GF and LS in combined commercial formulations by Method 2 .

\begin{tabular}{|c|c|c|c|}
\hline Formulation & \% Labeled Claim obtained AB & \% Labeled Claim obtained GF & \% Labeled Claim obtained LS \\
\hline Ascoril LS & $99.00 \pm 0.086$ & $99.51 \pm 0.342$ & $99.59 \pm 0.112$ \\
\hline
\end{tabular}

$\mathrm{d}$ - Mean and standard deviation for 10 determinations

Simultaneous equation method (Method 2)

Three equations were directly utilized for the simultaneous estimation of $\mathrm{AB}, \mathrm{GF}$ and $\mathrm{LS}$ in standard laboratory mixture as well as the marketed formulations. The developed method was validated accurately and results of accuracy were shown in Table 1, summary of various validation parameters were listed in Table 2, results of marketed formulation analysis were listed in Table 5.

Derivative ratio spectra zero crossing spectrophotometry (Method 3)

An accurate choice of either standard divisors or working wavelengths is fundamental for this method. In particular, by increasing or decreasing the concentration of divisor, resulting derivative values proportionately decreased or increased, with consequent variation of both sensitivity and linearity range. Several tests were made in a preliminary investigation by using standard divisors in the concentration range from 5 to $60 \mu \mathrm{g} \mathrm{mL}^{-1}$. The best results in terms of signal-to-noise ratio, sensitivity, repeatability, and range of validity of Beer's law were found by using $20 \mu \mathrm{g} \mathrm{mL}^{-1}$ of LS as divisor for $\mathrm{AB}$ and GF determination and $20 \mu \mathrm{g} \mathrm{mL}^{-1}$ of GF as divisor for LS determination. The first derivative wavelengths were considering $297 \mathrm{~nm}$ for AB determination, 275.6 $\mathrm{nm}$ for GF determination and $227.5 \mathrm{~nm}$ for LS determination. $297 \mathrm{~nm}$ was used for $\mathrm{AB}$ determination because there is not contribution of $\mathrm{GF}$ at this wavelength (20 $\mu \mathrm{g} \mathrm{mL}^{-1} \mathrm{LS}$ as divisor) shown in Fig. 4a. Similarly $275.6 \mathrm{~nm}$ was used for GF determination because it was zero crossing point for $\mathrm{AB}\left(20 \mu \mathrm{g} \mathrm{mL}^{-1} \mathrm{LS}\right.$ as divisor) shown in Fig. 4b. $227.5 \mathrm{~nm}$ was used for LS determination because at this wavelength $\mathrm{AB}$ had zero absorbance $\left(20 \mu \mathrm{g} \mathrm{mL}{ }^{-1} \mathrm{GF}\right.$ as divisor) shown in Fig. 4c. The developed method was validated accurately and results of accuracy are shown in Table 1, summary of various validation parameters are listed in Table 3, results of marketed formulation analysis are described in Table 6.

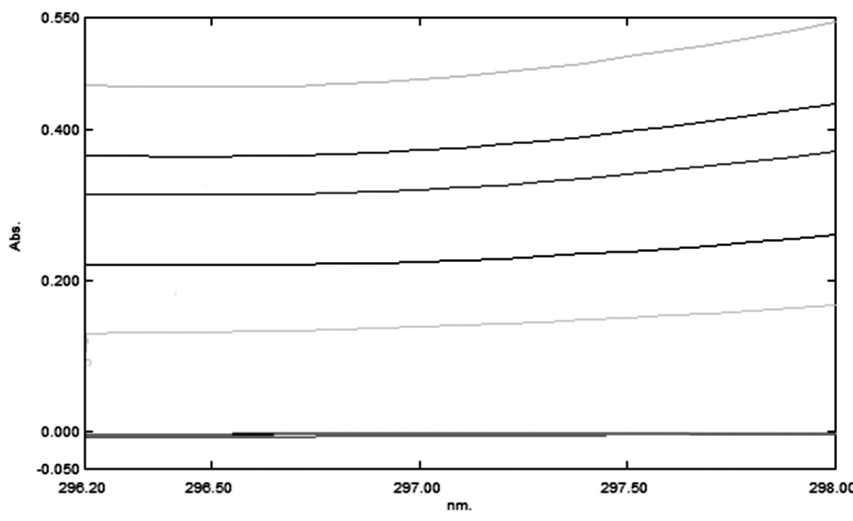

Figure4a: Determination of $\mathrm{AB}$ at 297 by Method 3 in the presence of GF using LS $\left(20 \mu \mathrm{g} \mathrm{mL}^{-1}\right)$ as divisor.

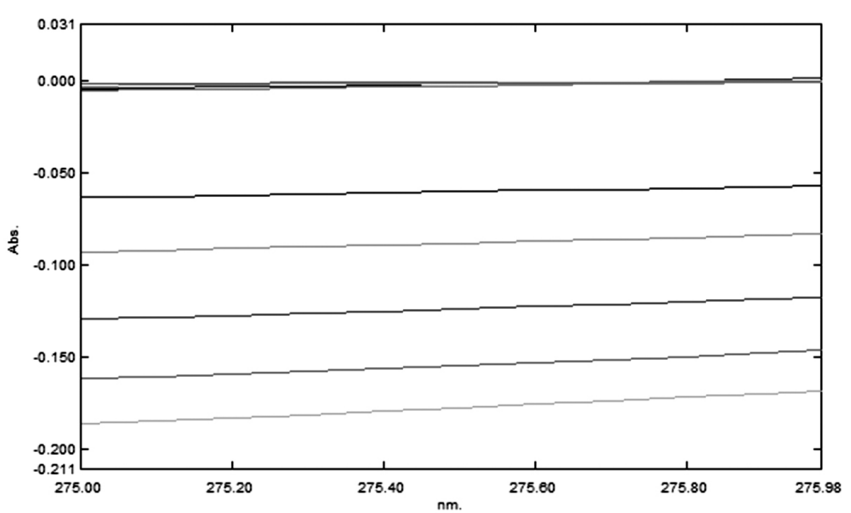

Figure4b: Determination of GF at $275.6 \mathrm{~nm}$ by Method 3 in the presence of $\mathrm{AB}$ using $\mathrm{LS}\left(20 \mu \mathrm{g} \mathrm{mL}^{-1}\right)$ as divisor.

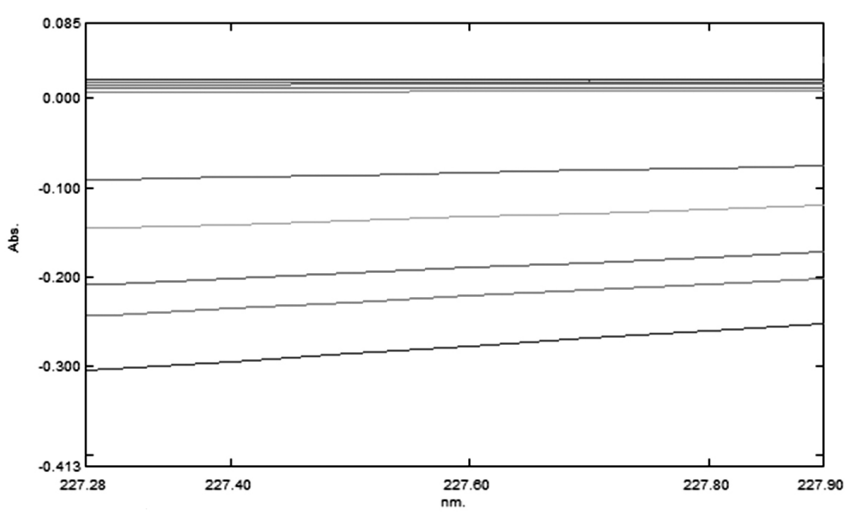

Figure4c: Determination of LS at $227.5 \mathrm{~nm}$ by Method 3 in the presence of $\mathrm{AB}$ using $\mathrm{GF}\left(20 \mu \mathrm{g} \mathrm{mL}^{-1}\right)$ as divisor.

Double divisor ratio spectra derivative method (Method 4)

In order to obtain the best spectra recoveries for $\mathrm{AB}, \mathrm{GF}$ and LS it is necessary to study and optimize parameters such as standard divisor concentration, scaling factor, delta lambda etc. The best results in terms of signal-to-noise ratio, sensitivity, repeatability, and range of validity of Beer's law were found by using a standard spectrum obtained by the addition of stored spectrum of $20 \mu \mathrm{g} \mathrm{mL}^{-1}$ of GF and $20 \mu \mathrm{g} \mathrm{mL} \mathrm{g}^{-1}$ of LS as divisor for $\mathrm{AB}$ determination. For GF determination, best results were obtained using a standard spectrum obtained by the addition of stored spectrum of $20 \mu \mathrm{g} \mathrm{mL}-1$ of $\mathrm{AB}$ and $20 \mu \mathrm{g}$ $\mathrm{mL}^{-1}$ of LS as divisor. Similarly for LS determination best results were obtained when a standard spectrum obtained by the addition of stored spectrum of 20 $\mu \mathrm{g} \mathrm{mL}^{-1}$ of $\mathrm{AB}$ and $20 \mu \mathrm{g} \mathrm{mL}^{-1}$ of $\mathrm{GF}$ is used as divisor. The first derivative wavelengths were considering $240.4 \mathrm{~nm}$ for $\mathrm{AB}$ determination, $262.4 \mathrm{~nm}$ for GF determination and $289.1 \mathrm{~nm}$ for LS determination. Wavelengths were selected on the basis of maximum amplitudes and best linearity represented in Fig. 5a-5c. The developed method was validated accurately and results of accuracy are described in Table 1, summary of various validation parameters 
were listed in Table 3, results of marketed formulation analysis are listed in Table 7.

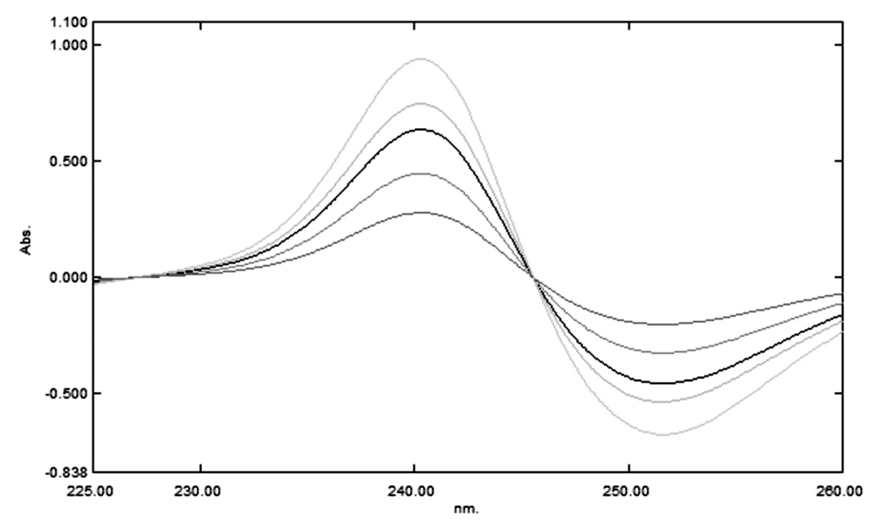

Figure5a: Determination of $\mathrm{AB}$ at $240.4 \mathrm{~nm}$ by Method 4 .

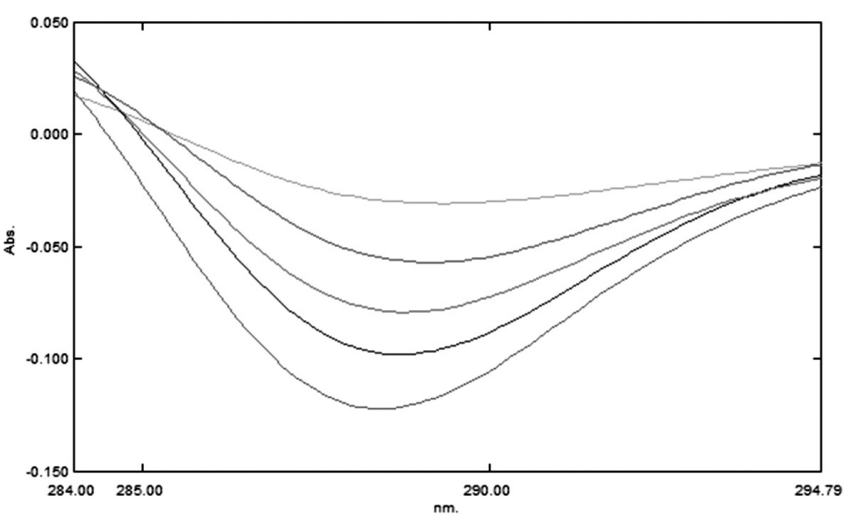

Figure5c: Determination of LS at $289.1 \mathrm{~nm}$ by Method 4 .

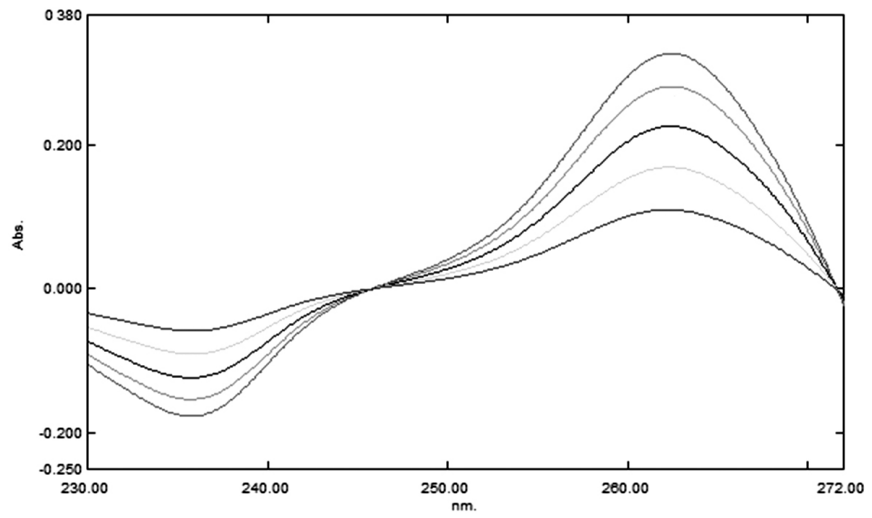

Figure5b: Determination of GF at $262.4 \mathrm{~nm}$ by Method 4 .

Table 6: Assay results of $\mathrm{AB}, \mathrm{GF}$ and $\mathrm{LS}$ in combined commercial formulations by Method 3 .

\begin{tabular}{|c|c|c|c|}
\hline Formulation & $\begin{array}{c}\text { \% Labeled Claim } \\
\text { obtained } \\
\text { For AB }\end{array}$ & $\begin{array}{c}\text { \% Labeled } \\
\text { Claim obtained } \\
\text { For GF }\end{array}$ & $\begin{array}{c}\text { \% Labeled } \\
\text { Claim obtained } \\
\text { For LS }\end{array}$ \\
\hline Ascoril LS & $98.67 \pm 0.003$ & $101.3 \pm 0.0005$ & $97.58 \pm 0.0001$ \\
\hline
\end{tabular}

d - Mean and standard deviation for 10 determinations

Table 7: Assay results of $\mathrm{AB}, \mathrm{GF}$ and LS in combined commercial formulations by Method 4 .

\begin{tabular}{|c|c|c|c|}
\hline Formulation & $\begin{array}{c}\text { \% Labeled } \\
\text { Claim obtained } \\
\mathrm{AB}^{\mathrm{d}}\end{array}$ & $\begin{array}{c}\text { \% Labeled Claim } \\
\text { obtained } \\
\mathrm{GF}^{\mathrm{d}}\end{array}$ & $\begin{array}{c}\text { \% Labeled } \\
\text { Claim obtained } \\
\text { LS }^{\mathrm{d}}\end{array}$ \\
\hline Ascoril LS & $102.07 \pm 0.0014$ & $99.09 \pm 0001$ & $99.22 \pm 0.0081$ \\
\hline
\end{tabular}

d - Mean and standard deviation for 10 determinations Statistical comparison of the results of the developed four methods

Proposed methods were successfully applied to the analysis of AB, GF and LS in combine pharmaceutical formulation without any interference of excipients and pretreatments. Results obtained were compared statistically by Student's $t$-test and by variance ratio $F$-test for each method. Calculated values of the Student's $t$-values at $95 \%$ confidence level and variance ratio $F$-values did not exceed the theoretical values indicating that there were no significant differences among the results of these developed four methods which is represented in Table 8.

Table 8: Statistical comparison of the results obtained by the developed four methods.

\begin{tabular}{|c|c|c|c|c|}
\hline Drugs & Method 1 & Method 2 & Method 3 & Method 4 \\
\hline \multirow{2}{*}{$\begin{array}{c}\mathrm{AB} \\
\text { Mean } \pm \mathrm{SD}\end{array}$} & $99.45 \pm 0.2345$ & $99.7 \pm 0.2345$ & $99.58 \pm 0.4214$ & $99.51 \pm 0.44$ \\
\hline & $\begin{array}{c}t_{\text {calculated }}=0.081 \\
t_{\text {theoretical }}=2.26\end{array}$ & $\begin{array}{c}t_{\text {calculated }}=0.081 \\
t_{\text {theoretical }}=2.26\end{array}$ & $\begin{aligned} t_{\text {calculated }} & =0.03 \\
t_{\text {theoretical }} & =2.26\end{aligned}$ & $\begin{array}{c}t_{\text {calculated }}=0.04 \\
t t_{\text {theoretical }}=2.26\end{array}$ \\
\hline \multirow{2}{*}{$\begin{array}{c}\text { BH } \\
\text { Mean } \pm \text { SD }\end{array}$} & $99.55 \pm 0.386$ & $99.75 \pm 0.999$ & $99.42 \pm 0.408$ & $99.44 \pm 0.8228$ \\
\hline & $\begin{array}{c}t_{\text {calculated }}=0.468 \\
t_{\text {theoretical }}=2.26\end{array}$ & $\begin{array}{c}t_{\text {calculated }}=0.081 \\
t_{\text {theoretical }}=2.26\end{array}$ & $\begin{array}{c}t_{\text {calculated }}=0.031 \\
t_{\text {theoretical }}=2.26\end{array}$ & $\begin{array}{c}t_{\text {calculated }}=0.088 \\
t_{\text {theoretical }}=2.26\end{array}$ \\
\hline \multirow{2}{*}{$\begin{array}{c}\text { ET } \\
\text { Mean } \pm \text { SD }\end{array}$} & $99.58 \pm 0.408$ & $99.42 \pm 0.4014$ & $99.47 \pm 0.563$ & $99.33 \pm 0.602$ \\
\hline & $\begin{array}{c}t_{\text {calculated }}=0.034 \\
t_{\text {theoretical }}=2.26\end{array}$ & $\begin{aligned} t_{\text {calculated }} & =0.05 \\
t_{\text {theoretical }} & =2.26\end{aligned}$ & $\begin{array}{c}t_{\text {calculated }}=0.022 \\
t_{\text {theoretical }}=2.26\end{array}$ & $\begin{array}{c}t_{\text {calculated }}=0.005 \\
t_{\text {theoretical }}=2.26\end{array}$ \\
\hline
\end{tabular}

Results obtained are average of ten experiments for each; SD, standard deviation.

\section{CONCLUSION}

All the newly developed spectrophotometric methods for simultaneous estimation of $\mathrm{AB}, \mathrm{GF}$ and $\mathrm{LS}$ are simple, specific, accurate, precise, rapid and economical which indicates its adequacy for routine pharmaceutical analysis.
It is concluded that derivative spectrophotometry is successfully utilized for simultaneous estimation of $\mathrm{AB}$, GF and LS in the combine dosage forms without any prior separation of individual drugs. In the absence of official monograph these validated methods can be use for determination of $\mathrm{AB}, \mathrm{GF}$ and LS. 


\section{ACKNOWLEDGEMENTS}

The authors express their sincere thanks to Divine Pharmaceuticals Pvt. Ltd and COSMOS Research Lab for supplying gift samples of pure AB, LS and GF. The research facilities provided by Mr. Praveen Garg (Chairman), ISF College of Pharmacy, Moga, Punjab (India) are also gratefully acknowledged.

\section{REFERENCES}

Government of India "Indian Pharmacopoeia” Vol. I, II, The Controller of Publications, Delhi, AB - 143250 701, (2007)

1. Government of India "Indian Pharmacopoeia" Vol. I, II, The Controller of Publications, Delhi, GF - 151315 1176, (2007)

2. "British Pharmacopoeia", Her Majesty's Stationary Office, London.GF - 317 S64, (1993)

3. S. Prabu, A. Shirwaikar, C. Kumar, G. Kumar, Ind. J. pharm. Sci. 70, 236-238, (2008)
4. S. Rahul, S.H. Kumar, S. Vinod, T. Shruti, J. Nilesh, Ind. J. pharm. Sci. 1, 41-49, (2011)

5. P. Parimoo, P. Umapathi, K. Ilango, Ind. J. pharm. Sci. 100, 227-231, (1993)

6. H.N. Dave, R.C. Mashru, A.R. Thakkar, Anal. Chim. Acta. 597, 113-120, (2007)

7. J.M.L. Gallego, J.P. Arroyo, Anal. Chim. Acta. 460, 85-97, (2002)

8. R.D. Acharya, B.D.Patel, V.V. Patel, J. Drug Delivery Therapeutics. 2, (2012)

9. S.S. Chitlange, R. Soni, S.B. Wankhede, A.A. Khukarni, Asian J. Research Chem. 2, (2009)

10. A.H. Beckett, J.B. Stenlake, Practical Pharmaceutical Chemistry. 4, 275 287 (1997)

11. A. Pathak, S.J. Rajput, Ind. J. pharm. Sci. 70, 513-517, (2008)

12. A. R. Rote, P. D. Bari, AAPS pharm. Sci. Tech. 10, 1200-1205, (2009)

13. A. Pathak, S.J. Rajput, J. AOAC. 91, 1059-69, (2008). 